\title{
The Many Faces of Art in Global Africa
}

\author{
By Jean M. Borgatti
}

Global Africa comprises all those parts of the world where more than 100,000 individuals of African descent live: the African continent, European countries that had significant colonial interests or trading networks (UK, France, Portugal, Holland), and those parts of the western hemisphere where European colonial and mercantile interests fostered the forced movement of people from Africa (the United States and Canada, the Caribbean, and portions of Central and South America--notably Brazil and neighboring countries). Global Africa in the context of Arts in a Global World includes the work of visual and performing artists who carried their cultures with them from Africa between the 16th and 19th centuries, those artists of African heritage in the Diaspora whose work focuses on the history of Africans in the Americas or who are inspired by African traditional art as well as those artists whose work appeals to an international market, though they remain resident in Africa, and those who are transnational (born in Africa but living and practicing elsewhere) or bi-cultural (of African descent but whose lives have been split between Africa and the Diaspora). This essay provides a summary overview of traditions in each of these categories, focusing in the last analysis on an international fashion designer of African descent (Ade Bakare) whose career trajectory epitomizes the situation of international artists of African heritage functioning in a global art economy today.

Keywords: Global, Africa, Diaspora, African-American, Art, Transnational, Bakaré

Global Africa comprises all those parts of the world where more than 100,000 individuals of African descent live today: the African continent itself, of course, and several of those European countries that had significant and long-term colonial interests or trading networks--the UK, France, Portugal, and Holland. Finally, Global Africa includes those parts of the western hemisphere where European trade and colonial interests fostered the forced movement of people from Africa (the Caribbean, portions of Central and South America (notably Brazil and neighboring countries), and the United States and by extension and over time, Canada - a place of refuge for enslaved peoples fleeing the United States prior to the $20^{\text {th }}$ century (http://www.compareafrique. com/the-african-diaspora-an-essential-part-of-development/).

Global Africa $^{1}$ in the context of Visual Arts in a Global world includes the work of artists who carried their cultures with them from Africa between the $16^{\text {th }}$ and $19^{\text {th }}$ centuries. The West Coast of Africa-- Senegambia (now Senegal and Gambia), Sierra Leone, the Windward Coast (Liberia and Ivory Coast), the Gold Coast (Ghana), the Bights of Benin and Biafra (Benin Republic and

\footnotetext{
* Professor, Department of Fine and Applied Arts, University of Benin, Nigeria.

${ }^{1}$ I have used the term "Global Africa" to reflect a particular demographic. This phrasing does more than reflect the idea of an African diaspora, for the Diaspora may include all places where people of African descent live without reference to their numbers in the population.
} 
Nigeria), and West Central Africa (Democratic Republic of Congo, Congo Republic and Angola) were the points of departure, but all these points drew populations from the interior (http://slavevoyages.org/tast/assessment/intromaps/01.jsp; Painter, 2006, pp.31-32).

Robert Farris Thompson and John Vlach ${ }^{1}$ are two of the pre-eminent scholars who, following in the footsteps of pioneering anthropologists Melville Herskovits and William Bascom, have focused on material culture or the visual and performing arts in their study of the origins of various diaspora traditions. Vlach's survey of Afro-American decorative arts first published in 1978 is a broad survey, directing attention to a wide range of black skills and talents as well as to the many contexts in which those skills were employed. Some of the works he discusses, represent the purest retention of African custom, while others reflect a blending of African and European forms and techniques.

Congo and Angolan cultures are particularly important in the formation stages of African cultures in the Americas. According to historian Nell Painter, more than one-third of the Africans transported to British North America and the United States came from the Kongo-Angola region. Considered the founding ancestors of African-Americans are twenty Ndongan men and women from west-central Africa who landed in Virginia in 1619 - not the first Africans but the first whose ethnicity was recorded (Painter, 2006, p.21). Over the next 250 years, some 500,000 Africans would be settled in the United States and Canada - roughly 5\% of the total number of Africans documented as arriving in the Western Hemisphere, a number totaling more than 11,000,000 (Painter, 2006, p.31).

Thompson writes that nowhere in the New World is the Kongo-Angola influence more profound than in black traditional cemeteries throughout the American south. He reminds us that the activating ingredients of the Kongo charm or sacred medicine is a human soul embodied by bone or grave dust. In the case of the graveyard, the coffin and the mound are the containers of the body and thus the soul, or as Thompson puts it, the "flash of the spirit." Decorative objects are placed on the grave that, in Kongo and the Americas, cryptically honor the spirit in the earth, guide it to the other world, and prevent it from wandering or returning to haunt survivors. The surface 'decorations' thus function as 'medicines' and mark a persistent cultural link between Kongo and the black New World (Thompson, 1984, p.132).

Both Kongo and black American tombs are frequently covered with the last objects touched or used by the deceased because they carry traces of the spirit, or are marked with white, symbolizing the realm of the dead. This idea underlies the white-washing of gravestones, sacrificing a white cock and/or

\footnotetext{
${ }^{1}$ I have relied heavily on Vlach and Thompson in a summary of the material effects of a dominant African presence in the New World between 1600-1900. Vlach focuses on the American South; Thompson extends his explorations into the Caribbean and Brazil. Though much work has been done since these two pioneering books were published (and Thompson's Flash of the Spirit was written long before it was actually published), most simply added detail to the broad picture they sketched out. I do not have a copy of Vlach's book with me in West Africa where I am writing this paper, and I am not able to be more specific in terms of page references. References to Vlach in this text refer to this publication.
} 
displaying white crockery or glass chickens on the grave, and lining the boundaries of the grave with white sea-shells (Thompson, 1984, p.134). Equally persistent in the American south is the Kongo-derived practice of garlanding trees with bottles, pots, and other objects for protecting the household through invoking the intercession of the dead (Thompson, 1984, p.142). Today, the bottle tree has become a modern art form, and a massive one stands in the courtyard of the African American museum in Dallas, Texas.

Some traditions reflect specific origins, such as the Kongo-derived traditions just discussed or the coiled grass baskets made in Georgia and the Carolinas in the United States that draw on West African forms and techniques from the areas of Senegal and Gambia. Others, notably percussion instruments and harps or chordophones, draw on multiple African traditions. If the most commonly used percussion instrument was a pair of hands -- clapped together, almost any object could serve as a surface for tapping out a rhythm. Though there need be no specific point of origin for drums in new world African cultures; drums made of hollowed logs with pegged heads were common to both the West Indies and the American South, and strongly resemble those made in southern Ghana (Ross, 1989). Indeed, an early $18^{\text {th }}$ century example collected in Virginia was deposited in the British Museum by 1753 (Powell, 2002, p.7, plate 1).

Similarly, the banjo as a folk instrument derives from the African harp, an instrument made and played by more than fifty cultures on the continent, each with a distinctive musical tradition (DeVale, 1989, p.53). In America, the banjo was considered an African instrument until the 1840's when minstrel shows adopted them for use in their black-face performances. Vlach (1978) notes that folk banjos with their wooden frames or gourd bodies, a fretless neck, a head of a groundhog or squirrel skin and gut strings clearly relate to African chordophones. Similarly, the resemblance of African and Diaspora cloths such as the Luiza Combs woven woolen blanket (Farrington, 2005, fig. 2.1) and certain African American quilts, especially those from Gee's Bend, as well as pieced cloths from Surinam, resemble one another and African prototypes because all share a guiding aesthetic principle of syncopated rhythm, and possibly a philosophical notion that staggering prevents being followed by evil spirits -- ideas that have African origins (Thompson, 1984, pp.207-222).

Vlach points out that a blend of European and African forms and techniques characterizes many craft activities that developed in America, hardly surprising since black people constituted half if not more of the labor force in the south. Canes produced by an active tradition of carving and whittling certainly have precedents in Africa where staffs indicate political or ritual status. American versions also display a similar careful smoothing of surfaces, finials in the form of human figures rendered symmetrically, geometric hatching, and serpent motifs (Vlach, 1978). African-American face vessels, objects made for African rather than European use, seem to be a blend of English Toby jugs and African face pots. The incorporation of white porcelain as eyes and teeth suggest a Kongo aesthetic (http://www.chipstone.org/html/ publications/CIA/2006/Newell/newellIndex.html). 
Smithing employed many individuals of African descent. A material link between the craft in Africa and the American south is provided by a wrought iron sculpture excavated at the site of a blacksmith shop and slave quarters in Alexandria, VA. This figure corresponds stylistically with Mande-style iron figures in both attitude and in the handling of mass and form. Since oneseventh of all Africans imported between 1710 and 1769 were from the Senegambian area, and Mande speakers would have fallen into this catchment area, this link is not simply a coincidence (Vlach, 1978, pp.136-138). However, the figure is an isolated example among ironwork done primarily for functional purposes, from farm equipment and weaponry to wrought iron grills and gates. Vlach asserts that much of the decorative ironwork found in the old French quarter in New Orleans or the old city of Charleston, SC was likely made by smiths of African descent and he has thoroughly documented the work of one, Philip Simmons of New Orleans.

Vlach (1978) includes the shotgun house on his list of Americana deriving from Africa. Shotgun houses are found commonly in black neighborhoods throughout the southern United States. He notes that they break a major convention of American folk housing by having the gable side, rather than the long side, face the road. The usual plan shows three or more small rooms directly connected to each other, forcing inhabitants either to prolonged, immediate interaction with one another, or out onto porch and street. Though described as houses without privacy, they are equally well-described as houses focused on community, like those in traditional African villages.

While Vlach focused on domestic material items, Robert Farris Thompson in his landmark book, Flash of the Spirit, called attention to African ritual activities and their material accessories carried into the Diaspora. In the Caribbean and South America, peoples from Nigeria and the Benin Republic left their cultural imprint on diasporic religious and self-help organizations. In Cuba, for example, the Abakua Brotherhood derives from the Leopard Society (Ekpe), a traditional governing association from Nigeria's Cross River region with its port at Calabar (Miller, 2009). Visual similarities between the Abakua masquerade and Ekpe's Ebonko masquerade make their historical ties evident. Both masquerades also serve a similar function within their organizations as the symbolic "mother" who brings all members of the association into the same family. An interesting change has occurred in the materials used for making Ebonko's costume, distinguishing it from the Abakua ireme masquerade. Ebonko's costume today comprises a sumptuous display of "modern" materials, a process begun as a result of access to international products linked to the slave and produce trades via the port of Calabar at the height of its prosperity during the $18^{\text {th }}$ century (Jordan Fenton, 2014, personal communication). Abakua's ireme masquerades changed less, retaining cotton cloth and raffia for costuming, since its members were concerned with maintaining links with their past.

Yoruba (Nigeria) and Fon people (Benin Republic) identified their own spiritual forces with specific Catholic saints and biblical figures, camouflaging their African identities. A discussion of the iconography of Cuban Santeria, 
Brazilian Candomble, and Haitian Vodoun is well beyond the scope of this paper. Shango, the deified fourth king of Oyo and Thundergod will be the only example used to illustrate this process. A "hot" or violent force, his color is red. He is identified with St. Barbara who is often shown with a crown, red robes, storm clouds and flashing lightning. Shango's regalia in the new world includes red garments, a crown, and the double axe symbol that refers to the Thundegod himself. The double axe is a pair of Neolithic stone celts, so called thunderstones that work their way to the earth's surface after violent rainstorms. Shango's staffs also carry the "double axe" motif as seen on examples from Nigeria, Cuba, and Bahia (Thompson, 1984, pp.84-97)

Moving away from the "retentions" in African cultures developed in the Americas and on to the work of more recent art made by university or artschool trained artists in the diaspora, it is clear that they continue to draw inspiration from Africa, from the entangled histories of Africa and the West, or from African culture as it manifests itself in the diaspora. Cuban artist Wilfredo Lam (1902-1982), for example, mixed Afro-Cuban religious vision with surrealism and cubism. He was a contemporary of Picasso but someone whose work is less well-known, since once he returned to Cuba from Paris, he was sequestered there (See Powell, 1997/2002, plate 71).

Lois Mailou Jones (1905-1998) whose career spanned more than seventy years, changed her references to Africa with the times, exemplifying the attitudes of her contemporaries. Egypt and Ethiopia were the focus in the 1920s and early 1930s. These were "high" cultures respected by elites in the West. A shift to sub-Saharan Africa occurred by the late 1930s, taking the form of visual quotations of traditional African masks and sculpture. By the time of the Civil Rights movement, her references to sub-Saharan Africa had taken a more strident and documentary stance.

Not just Africa, but Slavery and The Middle Passage, particularly the Slave Ship Brookes rendered infamous in a graphic depiction of how to fit the most human bodies into the confined space of the ship's hold, have become tropes in the work of such diaspora and transnational artists today as American artists Radcliffe Bailey (Thompson, 2010) and Willie Cole (Borgatti, 2009), Anglo-Nigerian artist Sokari Douglas Camp (www.sokari.co.uk), and the Benin Republic's Romuald Hazoume (http://www.britishmuseum.org/about _us/news_and_press/press_releases/2007/la_bouche_du_roi.aspx). Numerous others are illustrated in Painter's classic work Creating Black Americans (2006, pp.20-41).

The many faces of Global African art includes those artists of African heritage in the Diaspora today whose work focuses on the history of Africans in the Americas/Western World or who are inspired by traditional African art. Houston Conwill is an example of the former. Willie Cole and Renée Stout are examples of the latter. Conwill's The New Ring Shout (1995) celebrates a circle dance specific to southern African-American worship but has its roots in African dance patterns. Conwill's work (Painter, 2006, plate 3.1) is sited in the floor of a building built over New York City's African burial ground. The names of many specific ethnic groups, including Nigerian ones, reminds people 
walking on it that African diasporic identity is multi-cultural. Willie Cole takes a playful stance with his "bicycle" Chi Wara, antelope headdresses made of recycled bicycle parts (Borgatti, 2009) but Renée Stout creates a more emotionally fraught series of sculptures using a cast of her own body festooned with packets of magical medicine and an abdominal cavity containing personal ancestral relics - invoking her own ancestors for protection, following the methods of Kongo nkisi or magical medicine (McGaffey \& Harris, 1993).

Nigerian-American Nnenna Okore represents a slightly different category of African American - one who knows without DNA testing her African ancestry, the child of Nigerian parents. Raised in Nigeria, she graduated from the University of Nigeria, Nsukka, having studied with El Anatsui. She continued her education in the United States and is now based in Chicago where she teaches sculpture. She draws on textile forms in her practice but uses a range of materials, from fired clay to twigs and raffia to create texture and pattern. The work, Agbogbo Mmo (Maiden Spirit), refers to her own ethnic background which is Igbo as well as suggests the appliqué patterns of the masquerade's costume and the $19^{\text {th }}$ century hairstyles of the mask. She moves in the circle of the transnational artist, working in both Africa and America as well as exhibiting internationally (www.nnennaokore.com).

Okore follows a pattern of transnational artists who were born or raised in Africa but live and practice elsewhere. Ghana's Owusu-Ankomah and Nigeria's Sokari Douglas Camp are cases in point. Awusu-Ankomah was born in Secondi, Ghana, in 1956, and attended art school in the capital Accra. After several trips to Europe in the early 1980s, he established a studio near Bremen, Germany, where he currently resides and works. Owusu-Ankomah specifically makes use of African script systems in his work, particularly the symbols associated with Adinkra cloth. Adinkra means "good-bye" in the Twi language and was historically used as a funeral cloth, though today it may be used on celebratory occasions. The symbols stamped on the cloth refer to such concepts as strength, nurture, love, integrity, God, chieftaincy, and so on. (See www.owusuankomah.de for an overview of his work.) Sokari Douglas Camp is an artist whose work has been particularly reflective on her native culture (Kalabari Ijo) and the social problems of her country (Nigeria). Born in the Niger Delta, Camp was educated in Nigeria, England and the United States. Her masquerade series and installations feature Kalabari traditional forms, although they are often installed in ways that serve as a critique of the Western museum's focus on sculptural form. She has also been severely critical of exploitation and oppression in the Niger Delta through such works as Black Gold, a despoiled landscape framed with the jerry cans used to transport petrol and the Ken Sarowiwa living memorial. This is a life-sized bus that has the purpose of reminding the public of the 1995 murder of the Ogoni 9, a group of activists that included Sarowiwa. The group was executed by Sani Abacha's military government in order to suppress their political activism concerning the devastation wrought by oil extraction in the Niger Delta.

\footnotetext{
${ }^{1}$ See Sharon Patton (1998), Lisa Farrington (2005) and Richard Powell (1997/2002) for a broader overview of African-American art.
} 
There are as well some artists - though not many—whose work appeals to the International Art Market but who have stayed resident in Africa. Nigeria's El Anatsui and the Benin Republic's Romuald Hazoume are two such. El Anatsui, though Ghanaian born and educated, has taught at the University of Nigeria, Nsukka since the middle 1970s. He maintains a studio and practice there where he produces stunning textile-like forms out of recycled bottletops and cans. Like El Anatsui, Hazoumé works with common and recycled materials. His most dramatic work is an installation composed of 304 faces made from plastic jerry cans laid out in a pattern that mirrors the placement of the human cargo in the Brookes print. Evocative and disturbing, the installation includes sounds and smells, currencies and trade goods. It takes its name $L a$ Bouche du Roi (the Mouth of the King) from the point of embarkation in Benin for enslaved people during the 17th and 18th centuries. Hazoumé is one of the founders of the Fondation Zinsou in Cotonou, Benin, a gallery and cultural center oriented towards promoting contemporary art.

Looking at one individual within this global framework, provides additional insight into the psychological and intellectual struggle of artists of African descent as they develop their careers and find their place in an international community. Fashion designer Ade Bakare provides an excellent opportunity to understand what being global means for him as a transnational artist (Borgatti, 2015). ${ }^{1}$ Bakare was born in the UK and studied Fashion Design in Manchester, gaining his Higher National Diploma in 1990. He worked briefly for two internationally known London designers before setting up his own label in 1991. By the late 90s, he was selling his own collections twice a year to boutiques in the UK. Demand for designs from private clients encouraged him to open his own salon in Mayfair in 1996. His clientele is international-from Europe, the United States, Africa, the Caribbean--and his career is firmly based in Western fashion.

His work was exhibited in 2013 at a retrospective exhibition held at Terra Kulture, a gallery in Lagos. His gowns and dresses incorporated historic Yoruba textiles and textile design techniques, though these garments were less African in style than Western. However, his bio and timeline did not reference his Nigerian (specifically Yoruba) origins, or provide much information on his life in Nigeria. The first reference to Africa in his timeline occurs only in 2002, over a decade into his career. Since then he has developed an active relationship with the Nigerian world of high fashion. He became the official designer for First Lady Stella Obasanjo in 2004, opened his Lagos boutique in 2006, and established the Young Designers Creative Competition in 2007.

An interview with Bakare at his Lagos boutique in July 2013 revealed that though born in England, he attended secondary school and university in Nigeria, earning a degree in history at the University of Lagos. Only after he

\footnotetext{
1 A longer paper on Bakare was given at the $2^{\text {nd }}$ (non)Western International Fashion Conference, held in London in November 2013, and subsequently published (2015) in the International Journal of Fashion Studies, where his career was framed in the context of International fashion rather than in the context of Global African art. Illustrations of his work may be found in that article.
} 
had accomplished this, to satisfy his mother, did he feel free to return to a longheld ambition: going back to England to study fashion design.

When questioned about his timeline, Bakare responded by saying that when asked as a student and fledgling entrepreneur why he did not incorporate some element of his own background, something African, into his designs, he did not truly understand what they meant. During his formative years growing up and going to school in Nigeria, everything was Western - clothes, shoes, movies... No one, at least no one his age, was interested in "African" dress. It was not until he visited South Africa in 2005 that he understood what they meant by drawing from "African" culture and he began to incorporate traditional textiles such as aso oke, narrow bands of cloth woven by men, into his garments.

South Africa became an important turning point for Bakare with regard to introducing African elements into his designs. When he returned to South Africa in 2006, he brought an ensemble consisting of a headpiece inspired by a Yoruba crown with a fringe of beads covering the model's face, and a flowing cape with beadwork around the neck. His first thought had been to put a dress beneath the cape, recalling one of his signature designs - a jacket paired with dress or trousers. However, when the model dropped her cape, she caused a furor. She wore a bikini of gold lace and her body was wrapped in beads evoking a pre-colonial style of dress and decoration for young women. Flashbulbs popped, and it was on the front page of all the papers the next day.

After that, Bakare said: "I simply went African." He set his design team to research African textiles, particularly Nigerian traditional fabrics, and settled on adire - Yoruba resist-patterned cloth. Adire literally means "to tie and dye" and is the term used historically for indigo resist-dyed fabric, as well as today for any resist-dyed fabric-whether tie-dyed or batiked or whether dyed with indigo or not. In collaboration with his team, Bakare developed a modern concept through which he could utilize these techniques. Most important for his label, however, was that he was already established in England and had a customer base that did not expect him to be "African" in his designs. He was not categorized as an ethnic designer which left him free to introduce African effects without impinging on his status and reputation as an international designer. Free to be global.

He incorporates adire into jackets, blouses, and gowns featuring a painted design called basket weave that resembles a long linked chain and evokes patterns created by tying cloth before dyeing it. Indeed, this has become his signature "African" pattern used with variations on coats, dresses, and his new line of silk scarves.

Although successful in England, Bakare returned to Africa-and now splits his time between his London studio and his Lagos boutique. It was a business decision as well as a personal one. Global communications and technology have opened opportunities and facilitated working transnationally. Nigeria itself has a growing economy and is one of the world's most densely populated countries. Of course, Bakare is of Nigerian descent and proud of his Yoruba ethnic heritage. Like other transnational African artists, however, he is 
subject to the question "Why is there no Africa in your designs?" with the clear implication that if he wants to sell, he had better put some Africa into his designs. Such questions and their underlying assumptions, emphasize the "otherness" of the African artist, subtly undermining his or her creative agency and reinforcing the dominance of the West, even in a global art world.

In sum, this essay provides a glimpse, and only a glimpse, into some of the sites, situations, and players in the art world of a Global Africa. Africans have carried, and continue to carry, their creativity and their cultures (and please note the use of the plural here for Africa is a continent and not a country) to many parts of the globe. In the words of Sokari Douglas Camp, as made visible in her memorial project -- "All the World is Now Richer" (https://www.youtube.com/watch?v=bP670ylRhzg).

\section{References}

Bascom, W.R., 1980. Sixteen Cowries: Yoruba Divination from Africa to the New World. Indiana University Press.

Borgatti, J., 2009. Willie Cole's Africa Re-Mix: Trickster and Tribe. African Arts, 42(2), pp.12-23.

Borgatti, J., 2015. 'Why Africa? Why Now?' The Designs of Ade Bakar. International Journal of Fashion Studies, 2(1), pp. 99-113, doi:10.1386/ infs.2.1.99_1

DeVale, S. C., 1989. African Harps: Construction, Decoration, and Sound. In: M.T. Brincard, ed. Sounding Forms: African Musical Instruments. New York: American Federation of the Arts, pp. 53-62.

Farrington, L., 2005. Creating Their Own Image: The History of African-American Women Artists. Oxford University Press.

Herskovits, M., 1990. The Myth of the Negro Past. Beacon Press (Reprint edition)

McGaffey, W., \& Harris, M.D., 1993. Astonishment and Power. Smithsonian Institution.

Miller, I.L., 2009. Voice of the Leopard: African Secret Societies and Cuba. University Press of Mississippi.

Painter, N., 2006. Creating Black Americans: African-American History and its Meanings, 1619 to the Present. Oxford University Press.

Patton, S., 1998. African American Art. Oxford University Press.

Powell, R.J., 2002. Black Art and Culture in the Twentieth Century. Thames \& Hudson.

Ross, D.H., 1989. Master Drums from Akan Popular Bands. In: M.T. Brincard, ed. Sounding Forms: African Musical Instruments. New York: American Federation of the Arts, pp. 79-84.

Thompson, C., ed., 2010. Radcliffe Bailey: Memory as Medicine. Atlanta: DelMonico Books/Prestel for the High Museum.

Thompson, R.F., 1984. Flash of the Spirit: African and Afro-American Art and Philosophy. Vintage/Random House.

Vlach, J., 1978. The Afro-American Tradition in Decorative Arts. Cleveland Museum of Art. 
